\title{
Explaining BRICS Outreach: Motivations and Institutionalization
}

\author{
H. Zhao, D. Lesage
}

Huanyu Zhao - PhD, Researcher, Ghent Institute for International Studies (GIIS), Ghent University Department of Political Science; 8 Universiteitstraat, B-9000 Gent, Belgium; E-mail: huanyu.zhao@ugent.be

Dries Lesage - Associate Professor, Ghent Institute for International Studies (GIIS), Ghent University Department of Political Science; 8 Universiteitstraat, B-9000 Gent, Belgium; E-mail: dries.lesage@ugent.be

\begin{abstract}
This article examines and explains the outreach activity of the BRICS group of Brazil, Russia, India, China and South Africa. We focus on two research puzzles: a) the motivations and b) the form and degree of the institutionalization of BRICS outreach. We define outreach as collaborative interaction among BRICS and other actors within and outside the BRICS area and focus on outreach to governments of non-BRICS countries and national top officials representing regional organizations. First, we offer a theoretical framework based on the experiences of the Group of 7/8 (G7/8) and the Group of 20 (G20), considering both commonalities and differences with BRICS. Second, we provide a detailed empirical analysis of BRICS outreach over time. Third, we explain BRICS outreach in light of the theoretical framework and enrich it based on our findings. Methodologically, we draw empirical information from official documents, news media and academic literature. We argue that the outreach activity of a major power grouping is reflective of its internal cohesion, as well as of how it defines its own position in the world and how it is perceived by others. This research offers a timely contribution to the ongoing debate on BRICS and the underresearched BRICS outreach process as a part of the overall institutionalization of BRICS.
\end{abstract}

Key words: BRICS; outreach; BRICS Plus; Gx; motivation; institutionalization

For citation: Zhao H., Lesage D. (2020) Explaining BRICS Outreach: Motivations and Institutionalization. International Organisations Research Journal, vol. 15, no 2, pp. 68-91 (in English). DOI: 10.17323/1996-78452020-02-05

\section{Introduction}

Over the past decade, we have witnessed the development of BRICS as a major power grouping. Along with the deepening of the institutionalization of BRICS, the BRICS outreach concepts and practices are also gradually taking shape. Outreach towards the rest of world is related with two larger dimensions: how BRICS defines its role in global governance and how it gets institutionalized as an organization. Several scholars have already studied the interaction among BRICS and the wider geopolitical and multilateral system [Dijkhuizen, Onderco, 2019; Duggan, 2015; Shelepov, 2018]. Others have investigated the growth and institutional development of BRICS as such [Cooper, 2016; Kirton, 2015; Larionova, Shelepov, 2015; Stuenkel, 2015]. However, the why and how of BRICS outreach remain under-researched.

BRICS outreach can be defined as collaborative interaction among the BRICS actors (governments and institutions) and other actors within and outside the BRICS area, such as other governments, multilateral institutions, business and civil society. For the purpose of this 
paper, we focus on outreach to governments of non-BRICS countries and national top officials representing regional organizations. We leave out non-governmental actors and secretariats of multilateral organizations as this would amount to different research questions and theoretical implications.

Our research addresses two interrelated questions: 1) the motivations of the BRICS grouping for its outreach activity, and 2) the form and degree of institutionalization of the BRICS outreach. In the remainder of this paper, we offer a theoretical framework based on the experiences of the G7/G8 and the G20, considering both commonalities and differences with BRICS. As we will argue, the outreach activity of a major power grouping is reflective of its internal cohesion, as well as how it defines its own position in the world and how it is perceived by others. After presenting the theoretical framework, we provide a detailed empirical analysis of BRICS outreach. Next, we explain BRICS outreach in light of the theoretical framework, and enrich it based on our findings. Methodologically, we draw our empirical information from official documents, news media and academic literature.

\section{Gx Outreach Practices and Theoretical Framework}

In order to construct a theoretical framework to understand BRICS outreach, we draw inspiration from other major power groupings, namely the G7/G8 and G20 (the Gx groupings), whose outreach activities have a slightly longer history. After we have build-up the theoretical framework, we will apply it to the BRICS outreach and look for both commonalities and differences.

\section{The Motivations of Gx Outreach}

An initial fundamental question we have to ask is why a relatively small major power grouping would want to cooperate with non-member countries. Part of the purpose of the group relates to functions that can be fulfilled among the members themselves: coordinating macroeconomic policy, energy, environmental and other policies; coordinating diplomatic positions vis-à-vis the rest of the world; or peer learning. If the group cooperates directly with other countries, such activity requires specific explanation. It is a way to have an impact on those non-members, which can take several forms.

\section{Group Hegemony}

A useful concept, offered by the Canadian scholar Allison Bailin, to make sense of the outreach activity of the G7/G8 and G20, is "group hegemony." This concept, which was originally based on the G7 case, implies that the group as such undertakes a bid for hegemony in the global economy. The theory of group hegemony draws from hegemonic stability theory. In contrast to the latter, the former holds that the hegemonic function of keeping the global economy stable by providing global public goods and multilateral regimes is no longer assumed by a predominant great power alone, but by a group of powerful countries. This group (c.q. the G7) has taken over the role of a declining great power (c.q. the US), and is characterized by a concentration of economic power, a group identity and a commitment to economic liberalism [Bailin, 2005]. This theory resonates with what Keohane already observed in the early 1980s. With the single hegemonic power in decline, the underwriting of the multilateral system can be taken over by an "oligopoly," c.q. the G7 summits at that time [Keohane, 1984].

The concentration of power allows the group hegemon to provide for global public goods such as liquidity and the ability to act as the lender of last resort, large and wealthy consumer markets, foreign direct investment, and security functions. Literature on international coopera- 
tion maintains that the group should not be too small or too large. When it is too small, it cannot provide public goods. If it is too large, it faces high transaction costs and is unable to manage defection. In a group with the right size - the designate k-group - the members realize that the international public goods can only be achieved if all members contribute. Group identity adds to this commitment and the strong pressure not to defect. As powerful and competitive economies, the group members are keen to export and invest overseas. Hence they have a large stake in global financial-economic openness and stability [Bailin, 2005; Lake, 1993].

Bailin did not touch upon direct outreach to non-member countries, but does include G7 political control over multilateral institutions such as the International Monetary Fund (IMF) and World Bank Group (WBG) [Bailin, 2005]. Through this kind of institutional power [Barnett, Duvall, 2005], non-members are influenced in an indirect way. Still, direct outreach can be understood as bolstering group hegemony, more precisely by increasing group capacity, raising group legitimacy, and socialization of non-members into group visions (see below).

The theory is, besides the G7/G8 and BRICS, also applicable to the G20, including with regard to the outreach dimension. The G20 was created at finance ministers' and central bankers' level in 1999 in the wake of the Asian financial crisis and elevated to leaders' level at the zenith of the global financial crisis. The $\mathrm{G} 7$ had obviously become too small to fulfill the function of group hegemony in a world in which large emerging economies played key roles in international financial crises both as origins and solutions. However, a weakness of the G20 is the much lesser developed group identity.

In sum, the theory of group hegemony offers a theoretical framework to understand the creation and continuity of the G7/G8 and G20 and their role in the world economy and world politics. Their outreach to non-members supports this role. The question is to what extent this theory is applicable to the BRICS. In terms of economic power concentration the BRICS is far from being in a position to assume hegemony in the form of a "designate k-group." It has never displayed, let alone expressed such an ambition, unlike the pre-Asian-crisis-G7/8, which also used its outreach for this purpose (see below). However, most BRICS members have more and more interests abroad, and to support these interests, they are more and more active overseas. It would be logical if they used their collective BRICS platform for this purpose as well. As such, "group hegemony" can be seen as the advanced stage of a process, starting with the group's first steps to influence the global political economy in light of its own interests. Furthermore, another parallel between G7/8 and BRICS comes to mind. The G7 was created to complement the capabilities of the US as the declining hegemon. In a sense, we could argue that the BRICS complements the capabilities of the preponderant power in the BRICS, namely a rising China, that similar to the US, has an increasing stake in the course of the world economy and world order, and might be willing to instrumentalize the BRICS platform.

\section{Group Effectiveness Through More Capacity}

One motivation of direct outreach is to enhance the effectiveness of the group by bringing on board the capabilities of non-members for joint action. In the G7, after Canada and the EU became members in 1976 and 1977 respectively, we saw outreach to the Soviet Union and Russia in the 1990s, culminating in Russia's full-fledged membership in 1998 [Kirton, 2015].

The outreach partners contribute to the group's goals with their resources or with domestic reforms. With more participants come more capabilities. For the G8 in order to be able to meet its ambitions as a steering group for global governance, it had to bring in the loop countries such as the G5 (China, India, Brazil, Mexico, South Africa), whose policies have major impacts on the global economy, climate change or African development [Shaw et al., 2008]. At its summit in Evian (2003), the G8 decided to create the Africa Partnership Forum, which included 
11 other Organization for Economic Cooperation and Development (OECD) donor countries and African representatives [Blake, 2012]. Sometimes, it is primarily a matter of money: in 2010, the non-members Netherlands, New Zealand, Norway, Republic of Korea and Switzerland joined the G8 Muskoka Initiative pledging money to boost the Millennium Development Goals (MDGs) on maternal, newborn and child health [Bhuskan, Slahub, 2014]. For the time being, the capacity motive is less present in G20 outreach to other countries. This Gx experience leads us to a first hypothesis with regard to a materially driven motivation for outreach.

HYPOTHESIS 1: BRICS reaches out to non-member countries to increase its effectiveness in achieving its policy goals.

\section{Group Legitimacy}

Whereas the first motivation is driven materially, the next three are of a constitutive nature, i.e. aimed at shaping political positions, worldviews and identities of non-member countries. Both the G7/G8 and G20 have met contestation based on legitimacy grounds. The main reason is that they openly assumed a leadership role in global governance in general and thus affected the interests of non-member countries. The G7/G8 had gradually been expanding its agenda, and involving multilateral institutions such as the IMF, WBG and OECD, which are dominated by the G7/G8, but include many non-members. With its political clout and resources the G7/ G8 has also played an essential role in areas such as post-Soviet transition, the Asian financial crisis, and African development. The G20, in its turn, has led the response to the global financial crisis from its first 2008 leaders' summit onwards, by coordinating the national policies of 19 major economies plus the EU and tasking an array of international financial institutions. Inviting other countries to summits and other meetings, is a way to raise legitimacy through a) involving non-members in Gx decision-making, as well as b) allowing those leaders to enjoy the prestige vis-à-vis domestic and international audiences of participating in such powerful clubs.

From the 2000s onwards, the G8 realized it had to address this "crisis of legitimacy" [Shaw et al., 2008]. In 2000, Japan was the first G8 chair to invite African leaders to its summit in Okinawa [Cornelissen, 2012]. Since then until now, the G8 has always invited leaders of African countries to its summits (with an interruption in 2013 and 2014). At the 2003 Evian summit, France also invited the leaders of the rising powers China, India, Brazil, South Africa and Mexico. From 2005 until 2009, these so-called Outreach 5 (O5) or G5 leaders joined each G8 summit. However, the G8+5 format ceased to exist in 2009, when the G20 decided to continue as an annual leaders' summit [Kirton, 2015].

The birth of G20 summits changed the identity of the G8. The exit of Russia over the Ukraine crisis in 2014 reinforced the identity of the renewed G7 going back to its roots as the caucus of the major Western powers in a tense world. This evolution lowered the global governance ambitions of the G8, and concomitantly, the need to build-up legitimacy in the rest of the world. Still, in 2019, G7 chair France again invited India's prime minister, as an ad hoc initiative along with African and other leaders. This reflects a practice over the past 16 years of randomly inviting non-member countries, in addition to the now defunct G5 and ongoing Africa outreach.

The G20 has also developed an outreach practice to non-member countries. From the first summit in 2008 on, Spain has been invited as a "permanent guest." The prime minister of Netherlands has been invited several times, including in all summits since 2017. In addition, the G20 also invites the chairing countries of regional organizations, notably the African Union, NEPAD, ASEAN, and, irregularly, APEC and CARICOM. Already in 2009, the G20 got contested by a number of countries, including financial centers that disagreed with the G20 - OECD 
initiative at the London summit to list jurisdictions as non-cooperative tax havens. In response, Singapore convened the 30-member Global Governance Group (3G), which included other financial centers, such as Switzerland, along with a few other industrialized and developing countries. From the 2010 Seoul summit onwards, a 3G country - mostly Singapore - has always been present [Cooper, Momani, 2014; Luckhurst, 2016]. Hence, we can formulate a second hypothesis concerning outreach motivation:

HYPOTHESIS 2: BRICS reaches out to non-member countries to enhance its international legitimacy.

\section{Socialization of Non-Members into the Group Vision}

Outreach can be a group strategy to influence non-members, more precisely to reshape their governments' policies, views, and interests by socializing them into the group's consensus in terms of common interests and views. According to experts as well as outreach country officials, this intention was present in both the G8 outreach to Africa and to the G5 [Nafey, 2008; Woodward, 2008].

In July 2000, in the margins of the G8 Okinawa summit, the leaders of Algeria, Nigeria and South Africa met with the G8 leaders. Those three stood at the forefront of the call for a new African development strategy, which would resonate with the post-Washington Consensus or "Third Way" mindset of the G8 leaders at that time [Black, 2012; Cornelissen, 2012; G8, 2000]. In 2000-01, the governments of Algeria, Egypt, Nigeria, Senegal and South Africa promoted initiatives for African economic development that merged into the New Partnership for African Development (NEPAD). NEPAD was adopted by the Organization for African Unity (OAU, which turned into the African Union in 2002) in July 2001. The same month, in the presence of the leaders of Algeria, Mali, Nigeria and South Africa, it was endorsed by the G8 summit in Genoa [G8, 2001]. The joint G8 and NEPAD agendas revolved around the idea of Africa's own responsibility and a post-Washington Consensus vision including good governance, pro-market reforms, trade liberalization, as well as security, social development, water and agriculture. Although the new agenda for Africa partly originated from a few African governments themselves, G8 donors were always closely involved, and tried to consolidate their influence through endorsing activity [Black, 2012; Cornelissen, 2012; Engel, 2012; Taylor, 2012].

In the outreach effort to the G5, notably the Heiligendamm Process (HP) (2007-09), the agenda was unilaterally set by the G8 and largely reflected Western priorities [Leininger, 2009]. It included a) promoting cross-border investment, including corporate social responsibility, b) promoting research and innovation, including the protection of intellectual property rights,

c) fighting climate change, according to the principle of common but differentiated responsibilities and respective capabilities, d) cooperation on clean and renewable energy, and e) development, particularly in Africa [G8, 2007]. By opening profound dialogue on these topics, the G8 most likely aimed at socializing the G5 in its views and approaches. This strategy was strengthened by letting the OECD coordinate the process. The OECD is specialized in soft forms of governance that include peer-learning and sharing of best practices, often at technocratic levels. This offers a conducive environment for socialization. Woodward also points at the socialization potential and motive in involving the OECD in the HP: "Deeper participation in a body such as the OECD could have important socialization effects for the O5 countries exposing them, and possibly making them more amenable, to the norms of behavior in the OECD-G7/8 world" [Woodward, 2008, pp. 274-5]. The above analysis brings us to another hypothesis:

HYPOTHESIS 3: The BRICS reaches out to non-member countries to socialize them into shared BRICS views. 


\section{Instrumentalization of Group Outreach by Individual Group Members}

Adding non-members' capacities, increasing legitimacy and socialization of outreach partners as material and constitutive forms of interaction all help to consolidate group hegemony. However, outreach can also serve individual members' particularistic purposes. Individual group members might instrumentalize the group to advance their particular interests in relation to non-member countries. This motivation is different from the third when these individual interests are independent of the group consensus. In this case, that member utilizes the group as a power multiplicator, since the other members' hard and soft power capabilities are added to one's own.

In the G8 and G20, we only see a soft form of this motivation. In these bodies, the rotating chairs in particular as hosts of the summits possess an important amount of decision-making power over the outreach process during their presidency. Rotating chairs often invite nonmembers to beef up their bilateral ties. The invitees are often regional partners. For example, Japan $(2008,2016)$ and Canada $(2010,2018)$ invited respectively Asian-Pacific and American countries to their summits. G20 chairs sometimes invite regional partners, for example New Zealand at the 2015 Brisbane summit in Australia, Azerbaijan at the 2015 Antalya summit in Turkey, or Vietnam at the 2019 Osaka summit in Japan. Hence we can formulate a final hypothesis on motivation:

HYPOTHESIS 4: The BRICS reaches out to non-member countries for material or constitutive reasons upon the initiative of individual BRICS members in function of their individual interests.

\section{The Form and Degree of Outreach Institutionalization}

Institutionalization pertains to the questions of how the group organizes the outreach over time and to what extent continuity and consistency are achieved in involving non-members. Weak institutionalization would be characterized by a lack of organizational arrangements to sustain outreach over a longer term and quite irregular patterns of selecting and involving nonmembers. Strong institutionalization would be reflected in a serious organizational investment and stability of the patterns of outreach partners and activities. In sum, institutionalization rests on organization, consistency and longevity. Again, the Gx outreach experiences provide inspiration for theorizing.

The G8-Africa cooperation, or "Africa Outreach," got institutionalized quite rapidly. In Genoa in 2001, the G8 leaders decided to appoint personal representatives for Africa [Black, 2012]. In Evian in 2003, the G8 created the Africa Partnership Forum, which included 11 other OECD donor countries and African representatives. Even though there was never a fixed Africa outreach group, the leaders of Algeria, Egypt, Nigeria, Senegal and South Africa (who were invited several times) and others (in varying combinations), as well as the head of the African Union, were invited to most subsequent G8/G7 summits until the present. African development was there to stay on the G8 agenda, and often subject to comprehensive G8 plans. This relatively solid institutionalization can be linked to the G8 members' quite coherent post-Washington Consensus or "Third Way" mindset at that time (see 2.1.4).

The G8 was internally divided on the G8+5 format and the corresponding Heiligendamm Process. The UK, France and Germany were enthusiastic about this approach in order to enhance the legitimacy and impact of the G8. French and British leaders had already expressed their support for a full-fledged expansion to the G8. But the US were skeptical. For example they had not invited the G5 to their 2004 Sea Island summit [Shaw et al., 2008, p. 33]. The Bush administration tended to consider the $\mathrm{G} 8+5$ forum as a redundant talk-shop that undermined 
the value of intimate conversations among a small number of Western leaders. Japan and Canada, as non-members of the permanent group in the UN Security Council, were wary of seeing their relative weight diluted in a wider format, including Japan's Asian competitor China [Kirton, 2008]. These observations lead us to the first hypothesis concerning institutionalization:

HYPOTHESIS 5: Political cohesion within the group with regard to the outreach strategy leads to strong institutionalization. Consensus on the outreach strategy in its turn can be influenced by the overall political cohesion within the group.

We assume that outreach institutionalization partly depends on the attitudes of the outreach partners themselves. They should not be considered as passive players vis-à-vis the major power group's advances. In the case of the G8 Heiligendamm Process, it became known that some of the G5 partners were uncomfortable with the G8 dominance in the agenda-setting and procedure. The agenda was unilaterally set by the German chair and the G8, without consultation with the G5. G5 agenda suggestions were ignored. There was also unease about the role of the OECD that was tasked by the G8 to facilitate the process. China, India, Brazil and South Africa are not members of the OECD, which in the Global South is often regarded as a "rich men's club" [Cooper, 2008, pp. 14-5; Leininger, 2009; Nafey, 2008]. The specific problem here is that the G8 was engaging with other major powers, which self-identify as equals in a still asymmetrical format. In the new G20 summitry, the former G5 partners had at least a sense of full ownership as full members, rendering the G8+5 format immediately redundant. Probably, the G8+5 would have disappeared rather sooner than later even without the G20 summits. Outreach to smaller countries, in contrast, is very different, as they tend to accept the asymmetry of the relationship, and might be content to be invited to a quite prestigious table. In addition, as was visible in the G8 Africa outreach, some key African partners actively sought G8 support for their NEPAD initiative. This inspires a second hypothesis:

HYPOTHESIS 6: Institutionalization of outreach with major powers is hard to sustain without full ownership over the process. Smaller powers are more tolerant towards power asymmetry.

Table 1. Theoretical Framework and Hypotheses

\begin{tabular}{|l|l|l|}
\hline \multicolumn{1}{|c|}{ Explanandum } & \multicolumn{1}{|c|}{ Theories \& Perspectives } & \multicolumn{1}{c|}{ Hypotheses } \\
\hline $\begin{array}{l}\text { Motivations of Gx } \\
\text { outreach }\end{array}$ & $\begin{array}{l}\text { Group effectiveness through } \\
\text { more capacity }\end{array}$ & $\begin{array}{l}\text { HYP1: BRICS reaches out to non-member countries to increase } \\
\text { its effectiveness in achieving its policy goals }\end{array}$ \\
\cline { 2 - 3 } & Group legitimacy & $\begin{array}{l}\text { HYP2: BRICS reaches out to non-member countries to enhance } \\
\text { its international legitimacy }\end{array}$ \\
\cline { 2 - 4 } & $\begin{array}{l}\text { Socialization of non-members } \\
\text { into the group vision }\end{array}$ & $\begin{array}{l}\text { HYP3: The BRICS reaches out to non-member countries to } \\
\text { socialize them into shared BRICS views }\end{array}$ \\
\cline { 2 - 4 } & $\begin{array}{l}\text { Instrumentalization of group } \\
\text { outreach by individual group } \\
\text { members }\end{array}$ & $\begin{array}{l}\text { HYP4: The BRICS reaches out to non-member countries for } \\
\text { material or constitutive reasons upon the initiative of individual } \\
\text { BRICS members in function of their individual interests }\end{array}$ \\
\hline $\begin{array}{l}\text { The form and } \\
\text { degree of outreach } \\
\text { institutionalization }\end{array}$ & $\begin{array}{l}\text { Political cohesion } \\
\text { HYP5: Political cohesion within the group with regard to the out- } \\
\text { reach strategy leads to strong institutionalization. Consensus on } \\
\text { the outreach strategy in its turn can be influenced by the overall } \\
\text { political cohesion within the group }\end{array}$ \\
\cline { 2 - 3 } & Power asymmetry & $\begin{array}{l}\text { HYP6: Institutionalization of outreach with major powers is hard } \\
\text { to sustain without full ownership over the process. Smaller pow- } \\
\text { ers are more tolerant towards power asymmetry }\end{array}$ \\
\hline
\end{tabular}




\section{Exploring the BRICS Outreach: Empirical Findings}

\section{Situating the BRICS Outreach in the Process of BRICS Institutionalization}

The development of BRICS outreach concepts and practices should be situated in the overall process of BRICS institutionalization. Against the backdrop of the 2007-09 global financial crisis (GFC) and the reduced legitimacy of the G7/G8 in global governance, the relatively resilient BRIC countries began to enhance political cooperation through the BRIC platform and better use their temporarily increased bargaining power to be effective agenda setters [Stuenkel, 2013]. From then on, the BRICS outreach is gradually taking shape along with the development of the institutionalization of BRICS grouping as such.

At the very beginning of the BRIC cooperation in 2009, the outreach concept was not explicitly raised. The first instance of BRIC outreach can be dated back to the accession of South Africa. In 2010, the president of South Africa Jacob Zuma was invited for the first time as a guest at the BRIC Brasília Summit. In the following year under China's presidency, the Sanya Summit resulted in an important strategic decision: incorporating South Africa as its full member, adding the $\mathrm{S}$ to BRICS.

Although the economic power of South Africa is hardly comparable with the other four countries, its inclusion has profound political and outreach implications. Because of Johannesburg's leading role in Africa and membership in the G20 and other multilateral arrangements, it enhanced the coverage, representativeness and geopolitical influence of the BRICS as a group of rising powers. The BRICS became a unique major power grouping bringing together five different rising powers from four continents without the participation of the US or any other established power.

As stated in the 2011 Sanya Declaration, BRICS cooperation is "open to increasing engagement and cooperation with non-BRICS countries, in particular emerging and developing countries, and relevant international and regional organizations" [BRICS, 2011]. Since then, the outreach has evolved as part of the evolution of the BRICS institutionalization.

\section{One Outreach, Two Formats, Dual Channels}

From 2013 onwards, we observe that the BRICS outreach with non-BRICS countries is mainly based on two formats: the BRICS regional outreach and the BRICS Plus (also known as BRICS+). BRICS regional outreach consists of networking with the respective rotating presidency's sub-regions. Under the rotating presidency, BRICS takes its geopolitical advantage by strengthening institutional links with its sub-regions and enhancing South-South dialogue. BRICS Plus, in contrast, is not restricted to respective sub-regions but rather offers a flexible, diverse, open approach to networking with diverse partners. In addition, the BRICS outreach occurs through various channels, but is most visible through its summits and own institutions.

Table 2. The BRICS Outreach

\begin{tabular}{|l|l|l|l|}
\hline \multicolumn{2}{|c|}{ BRICS outreach } & \multicolumn{1}{|c|}{$\begin{array}{c}\text { Networking with non-BRICS countries, in particular emerging and developing countries, } \\
\text { and relevant international and regional organizations }\end{array}$} \\
\hline Formats & $\begin{array}{l}\text { Regional } \\
\text { Outreach }\end{array}$ & $\begin{array}{l}\text { Networking with countries } \\
\text { and organizations in the re- } \\
\text { spective rotating presidency's } \\
\text { sub-regions }\end{array}$ & $\begin{array}{l}\text { E. g. Africa Union (AU), the Union of South American } \\
\text { Nations (UNASUR), the Community of Latin American } \\
\text { and Caribbean States (CELAC), the Shanghai Coopera- } \\
\text { tion Organization (SCO), the Eurasian Economic Union } \\
\text { (EAEU), Bay of Bengal Initiative for Multi-Sectoral Tech- } \\
\text { nical and Economic Cooperation countries (BIMSTEC) }\end{array}$ \\
\hline
\end{tabular}




\begin{tabular}{|c|c|c|c|}
\hline \multicolumn{2}{|c|}{ BRICS outreach } & \multicolumn{2}{|c|}{$\begin{array}{l}\text { Networking with non-BRICS countries, in particular emerging and developing countries, } \\
\text { and relevant international and regional organizations }\end{array}$} \\
\hline Formats & $\begin{array}{l}\text { BRICS Plus } \\
(\text { BRICS }+)\end{array}$ & $\begin{array}{l}\text { Flexible, diverse, open } \\
\text { networking with varying } \\
\text { countries and organizations } \\
\text { (in varying combinations) }\end{array}$ & $\begin{array}{l}\text { Egypt, Guinea, Mexico, Tajikistan, Thailand, Argentina, } \\
\text { Indonesia, Jamaica, Turkey }\end{array}$ \\
\hline \multirow[t]{2}{*}{ Channels } & Summits & $\begin{array}{l}\text { Hosting Joint Summit, invit- } \\
\text { ing partners and guests }\end{array}$ & $\begin{array}{l}\text { E. g. the BRICS - Africa Outreach, Joint summit with } \\
\text { SCO-EAEU, Joint summit with BIMSTEC }\end{array}$ \\
\hline & $\begin{array}{l}\text { BRICS- } \\
\text { institution }\end{array}$ & $\begin{array}{l}\text { BRICS New Development } \\
\text { Bank }\end{array}$ & $\begin{array}{l}\text { Membership: the NDB Agreement states it shall be open to } \\
\text { members of the United Nations and shall be open to bor- } \\
\text { rowing and non-borrowing members [BRICS, 2014b]. } \\
\text { Regional offices: Africa Regional Center in Johannesburg } \\
\text { (South Africa), Americas Regional Office in Sao Paulo } \\
\text { (Brazil), sub-office in Brasília (Brazil), Eurasian Regional } \\
\text { Centre Moscow (Russia). } \\
\text { Global Partnership: Multilateral Development Banks } \\
\text { (MDBs), National Development Banks, Commercial } \\
\text { Banks, Multilaterals, Enterprises, Academia [NDB, 2020] }\end{array}$ \\
\hline
\end{tabular}

\section{The BRICS Outreach/Plus via Summit}

\section{Regional Outreach with Africa}

The very first BRICS outreach practice with its regional partners started in 2013. In March 2013, South Africa hosted the 5th BRICS summit in Durban under the theme entitled "BRICS and Africa: partnerships for development, integration and industrialization." For the first time, the BRICS leaders invited the African Union (AU) to join the summit. At the Summit, BRICS leaders agreed to establish the New Development Bank (NDB) and the BRICS Contingent Reserve Arrangement (CRA). After the Summit, a retreat was held by BRICS leaders and 15 African leaders under the theme: "Unlocking Africa's potential: BRICS and Africa Cooperation on Infrastructure" [BRICS, 2013]. The BRICS stated in the eThekwini Declaration: "We are open to increasing our engagement and cooperation with non-BRICS countries, in particular Emerging Market and Developing Countries (EMDCs), and relevant international and regional organizations." Consequently, BRICS regarded the retreat as "an opportunity for BRICS and African leaders to discuss how to strengthen cooperation between the BRICS countries and the African continent" [Ibid., 2013]. In the retreat, sustainable infrastructure development in Africa was deemed as critical to promoting its regional integration and industrialization and as an important area for the BRICS to support.

\section{Regional Outreach with South America and Latin America}

Following the same format, in July 2014, Brazil hosted the 6th BRICS Summit in Fortaleza under the theme of "Inclusive Growth: Sustainable Solutions." Leaders of the Union of South American Nations (UNASUR) and the Community of Latin American and Caribbean States (CELAC) were invited to attend the Summit and discussed "shared interests" with BRICS leaders [Ibid., 2014c]. The BRICS leaders declared: "We renew our openness to increasing engagement with other countries, particularly developing countries and emerging market economies, as well as with international and regional organizations, with a view to fostering cooperation and solidarity in our relations with all nations and peoples" [Ibid.]. BRICS leaders believed that the strengthened dialogue among BRICS and South American countries can play an active role in enhancing multilateralism and international cooperation. Moreover, 
they reiterated their commitment made during the BRICS Leaders-Africa Retreat at the 5th BRICS Summit to foster and develop BRICS - Africa cooperation in support of the socioeconomic development of Africa, particularly with regard to infrastructure development and industrialization.

\section{Regional Outreach with Eurasia}

In July 2015, under the theme of "BRICS Partnership - a Powerful Factor of Global Development," the 7th BRICS Summit, the 15th Shanghai Cooperation Organization (SCO) Summit and the Eurasian Economic Union (EAEU) Summit were jointly held by Russia in Ufa [BRICS, 2015]. It offers an interesting prism to see how the BRICS platform and outreach linkages serve the interests and goals of BRICS member states. First, against the backdrop of the Ukraine Crisis, Russia became isolated in international affairs. It was put under EU and US sanctions, and its membership of the G8 was suspended. Hence the importance for Russia's economic and foreign policy of the G20, BRICS, SCO, and EAEU markedly increased. The joint summit offered a multi-channel for Russia to gain support from and deepen practical cooperation with its partners (especially Russia and China in this case, so-called "Sino-Russian rapprochement") and strengthen its international status. For instance, on 8 May 2015, two months prior to the summit, Russia and China had signed a Joint Statement on the cooperation in docking the Belt and Road Initiative (BRI) and construction of the EAEU, opening up new prospects for deepening practical cooperation among the member states of the SCO [Kremlin, 2015]. Beyond its traditional security and political focuses, the SCO started to gradually develop the dimension of economic cooperation, and its function of linking the EAEU with BRI was further discussed during the summit. After the summit, the joint SCO-BRICS Business Forum as well as the BRICS and SCO Youth Forum were held by Russia.

\section{Regional Outreach with South Asia and Southeast Asia}

In October 2016, in order to further reach out and enrich understanding and engagement with developing and emerging economies, the BRICS - BIMSTEC Outreach Summit (BIMSTEC, Bay of Bengal Initiative for Multi-Sectoral Technical and Economic Cooperation comprising Bangladesh, Bhutan, India, Myanmar, Nepal, Sri Lanka and Thailand) was hosted under the theme "Building Responsive, Inclusive and Collective Solutions" by India in Goa [BRICS, 2016]. BRICS regarded the Outreach Summit as an opportunity to renew friendship with BIMSTEC countries as well as to jointly explore possibilities of expanding trade and commercial ties, and investment cooperation between BRICS and BIMSTEC countries [Ibid.]. The BIMSTEC, sometimes referred to as mini SAARC (South Asian Association for Regional Cooperation), lacks regular summit record and visibility. For BIMSTEC, the outreach summit offered a superior channel to boosting ties with emerging powers and enhancing its visibility. The two groupings discussed matters of mutual interest, exchanged views on global and regional issues including the United Nations 2030 Agenda for Sustainable Development. After the Retreat, the BIMSTEC Leaders released the 2016 Retreat Outcome Document which emphasized the value of outreach in generating trust and understanding as well as promoting further cooperation among countries of the two groupings [BIMSTEC, 2016].

\section{Outreach with Flexible and Diverse "Plus"}

Building on a similar format, facing criticisms on BRICS as an exclusive club [de Coning, 2017], and going beyond outreach with respective sub-regions, a new concept and outreach format was introduced under China's 2017 presidency: "BRICS plus." It was first 
mooted by Chinese Foreign Minister Wang Yi at a press conference for the 5th session of the 12th National People's Congress in Beijing, March 8, 2017. Wang said BRICS would "build a new platform for south-south cooperation, exploring a "BRICS plus" format by holding dialogues with other major developing countries or groups of developing countries to establish a more extensive partnership" and "widen the circle of friends of the BRICS and turn it into the most influential platform for south-south cooperation in the world" [Xinhua, 2017]. It was defined more clearly prior to the Summit. On 30 August 2017, responding to journalists at a briefing held by the Ministry of Foreign Affairs on the 9th BRICS Summit and Dialogue between EMDCs, Wang Yi noted that the idea of the "BRICS Plus" format is "openness, inclusiveness, cooperation and mutual benefits," which is highly consistent with the BRICS spirit. The purpose of the "BRICS Plus" format is to strengthen dialogue and cooperation between BRICS countries and other EMDCs, promote the establishment of broader partnerships and facilitate common development and prosperity on a larger scale [Ministry of Foreign Affairs of the PRC, 2017a].

Four days later, the 9th BRICS Summit was hosted under the theme "BRICS: Stronger Partnership for a Brighter Future" by China in Xiamen on 3 September 2017. During the summit, the BRICS Plus cooperation format was formally launched by China. Giving a keynote speech at the opening ceremony, Chinese President Xi Jinping [Ibid., 2017b] said "we should expand the coverage of BRICS cooperation and deliver its benefits to more people. We should promote the "BRICS Plus" cooperation format and build an open and diversified network of development partnerships to get more emerging market and developing countries involved in our concerted endeavours for cooperation and mutual benefits.” The leaders of Egypt, Guinea, Mexico, Tajikistan, and Thailand were invited to the Dialogue of Emerging Market and Developing Countries under the theme "Strengthening Mutually-Beneficial Cooperation for Common Development" [BRICS, 2017]. The "BRICS Plus" was also featured in the Xiamen Declaration: "We shall also strive towards broad partnerships with EMDCs, and in this context, we will pursue equal-footed and flexible practices and initiatives for dialogue and cooperation with non-BRICS countries, including through BRICS Plus cooperation” [Ibid.].

The promotion of the BRICS Plus format can be interpreted in the context of the change of China's BRICS policy orientation. China wants to combine the BRICS and the BRI and put itself in a leadership role. Both BRICS and BRICS Plus are by the Chinese side seen as a mechanism to negotiate [Hooijmaaijers, 2019]. The Belt and Road Portal, for instance, mentions the BRICS' synergy with the BRI, as it states that "Although China's economy has surpassed the other four members of the BRICS bloc combined, China is willing to share its development premiums with them and the other developing countries. An important way is to form an extensive partnership network. BRICS and the BRI are both striving in the same direction" [Li, 2017].

Despite China's effort to promote the BRICS Plus format, it has received divergent responses from other BRICS members. The other four member countries remain wary of China's predominance in BRICS and its increasing influence in the Global South, especially India [Dasgupta, 2017; Purushothaman, 2019; Siddiqui, 2017]. Fearing China utilizes the group as a power multiplicator, considering China's wider global strategy particularly through its BRI, India's concern is that the Plus format would boost China's influence while potentially eroding that of the other members. In the run-up to the 9th BRICS Summit held in China, the Indian delegates attending the academic forum in Fuzhou were steadfastly opposed to docking the BRI with the BRICS in the future [Naidu, 2018]. China had initially proposed the list of prospective members, which includes a diverse crowd from the Global South: Bangladesh, Egypt, Indonesia, Iran, Mexico, Nigeria, the Philippines, South Korea, Turkey and Vietnam 
[Mpungose, 2017]. However, due to limited consensus within the grouping, only five countries mentioned above were invited to the Summit. The coherence of the outreach strategy has been challenged by its members' divergent interests and concerns.

\section{Parallel Regional Outreach With Africa and Diverse "Plus"}

Building on the innovation of China, South Africa opted for a synthesis of the regional outreach format and the Plus format. From 25 to 27 July 2018, under the theme of "BRICS in Africa: Collaboration for Inclusive Growth and Shared Prosperity in the 4th Industrial Revolution," the 10th BRICS Summit was held by South Africa in Johannesburg [BRICS, 2018].

The BRICS Africa outreach session and BRICS plus session were held on the last day of the Summit on 27 July 2018. At noon, BRICS leaders invited the leaders of Ethiopia, Angola, Zambia, Namibia, Senegal, Gabon, Togo, Uganda, Rwanda (AU chair), and SADC leaders to the BRICS Africa outreach dialogue. Later, in the afternoon, BRICS leaders had Argentina (as Chair of the G20 and influential MERCOSUR member), Indonesia (as Co-Chair of the New Africa - Asia Strategic Partnership with South Africa and influential ASEAN member), Egypt (as Chair of the G77+China), Jamaica (as incoming Chair of Caribbean Community, CARICOM) and Turkey (as Chair of the Organization of Islamic Cooperation, OIC) at the BRICS Plus Initiative session. In total, 21 countries including emerging markets and African countries took part in the BRICS Plus leaders' dialogue.

After the Summit, China's South Africa ambassador Lin Songtian [Embassy of the People's Republic of China in the Republic of South Africa, 2018] made a long remark and highlighted the tangible and intangible benefits of the BRICS and the BRICS Plus mechanism for the host and partners. He praised how the Summit had further improved the BRICS Plus mechanism and expanded the developing partnership network of the BRICS "circle of friends." The outreach and BRICS Plus formats operated as tools for the soft involvement of geographically distant countries, located in different regions of the world, in joint activities on issues of mutual interest. Besides, following the BRICS-SCO-EAEU joint Summit in 2015, under the auspices of Russia, an agreement was concluded in 17 May 2018 between China and EAEU members to strengthen trade and economic cooperation, and many of the projects envisioned are part of the BRI [EEC, 2018].

\section{Stalled Outreach?}

From 2013 till 2018, it seems that BRICS outreach practices - the regional outreach format and BRICS Plus format - had found some continuity. Over the past years, albeit dynamically, such practices had helped the members of BRICS and especially the hosts to further engage with their respective regions and diverse partners on common interests. However, neither a regional outreach nor the plus session took place during the 11th BRICS Summit on 13 and 14 November 2019 in Brasília. The Bolsonaro government insisted on inviting Venezuela's Juan Guaidó to the Outreach Summit. However, all other BRICS members do not recognize Guaidó as president. Brazil decided to cancel the Outreach Summit altogether before the Summit. Since 2013, this was the first time that the Outreach Summit did not happen and the move was privately criticized by diplomats from the other BRICS countries [Stuenkel, 2019].

This stalled outreach reflected a lack of cohesion on BRICS members' outreach strategies and priorities. Before the summit, at many meetings and occasions, China made it clear that it wanted the BRICS Plus to happen in 2019 [Ministry of Foreign Affairs of the PRC, 2019a; 2019b; 2019c]. Although the outreach was canceled, during the Summit, at the BRICS Business Forum on 13 November and in a formal statement on 14 November, Xi continually called on 
the BRICS countries to leverage "BRICS Plus" cooperation as a platform to increase dialogue with other countries and civilizations and for BRICS to win more friends and partners [Ministry of Foreign Affairs of the PRC, 2019d; 2019e].

\section{The BRICS Outreach/Plus via BRICS Institution: New Development Bank}

Over the past decade, we have witnessed the intensification of BRICS institutionalization. Beyond outreach via summits, the establishment of BRICS' own institutions have made one more channel for its outreach.

Since 2012, BRICS has started working on establishing its own institutions. In 2014, significant progress of the BRICS institutionalization has been made - the Treaty for the Establishment of Contingent Reserve Arrangement and the Agreement on the New Development Bank were signed by BRICS leaders at the Fortaleza Summit. The former is a framework for the provision of support through liquidity and precautionary instruments in response to actual or potential short-term balance of payments pressures [BRICS, 2014a]. However, since the membership of CRA doesn't open to non-BRICS countries, we leave it out of our analytical focus. The latter is formed to support infrastructure and sustainable development efforts in BRICS and other underserved, emerging economies for faster development through innovation and cutting-edge technology [NDB, 2019a]. The Bank's initial subscribed capital is US\$50 billion and became fully operational in 2016 [Ibid., 2016]. A closer look at the of development of NDB reveals following outreach features.

\section{Open Membership}

In terms of the membership, the NDB Agreement states it shall be open to members of the United Nations and shall be open to borrowing and non-borrowing members [BRICS, 2014b]. As being formulated, the Agreement gives the NDB a built-in outreach feature. This has laid the groundwork for the NDB to have substantial outreach, expansion, and cooperation with non-BRICS countries in the foreseeable future. In the 2019 Summit, notwithstanding neither of the regional outreach nor the plus session happened, for the first time, the leaders of BRICS put membership expansion of the NDB on agenda. As stated in the Brasília Declaration [Ibid., 2019], the expansion of the NDB membership in accordance with its Articles of Agreement will strengthen the Bank's role as a global development finance institution and further contribute to the mobilization of resources for infrastructure and sustainable development projects in BRICS and other EMDC's.

\section{Regional Centres/Offices}

Being aware that member countries have different systems and processes for project origination, the NDB has invested in learning to work with these systems and adopted countryspecific approaches since its inception [NDB, 2019b]. As set in the Articles of Agreement, the NDB may establish offices necessary for the performance of its functions [BRICS, 2014b]. And as further clarified in the NDB's General Strategy, identification and preparation of bankable projects in BRICS and other member countries are the main functions of the Bank's regional offices [NDB, 2017a].

We have seen that after the Bank's headquarters was built in Shanghai in 2016, three regional offices were established year by year. The first regional office of the NDB - Africa Regional Center (ARC) - was officially opened in Johannesburg on 17 August 2017. This is an important milestone for the Bank to set the ARC as an outreach office for sustainable infrastructure development in South Africa and as a visible participant in the development agenda 
of the continent [NDB, 2017b]. On 26 July 2018, the second agreement - for the hosting of NDB's Americas Regional Office (ARO) in São Paulo - was signed [Ibid., 2018]. On 13 November 2019, the NDB and the Government of Russia Federation signed the Agreement on the hosting of the New Development Bank Eurasian Regional Centre (ERC) in the Russian Federation [Ibid., 2019c]. According to the Agreement, the ERC will be located in Moscow. Based on the NDB's business needs, the Bank may also establish premises in other cities within Russia [Ibid., 2019d].

These regional centers/offices play several roles for the NDB and its outreach. For instance, the ARC's role was defined by NDB President Kamath [Ibid., 2017c]: a) its initial role consisted of identification and preparation of projects in South Africa. This is in line with South Africa's National Development Plan, which the Government has adopted as a blueprint for the future economic and socio-economic development strategy for the country. The NDB and the ARC aim to partner with the Government in the achievement of these goals. In particular, the ARC plays an important role in preparing these projects so that they can be financed and supports the effective and efficient implementation of these projects. Furthermore, as the activities of the ARC will expand both in scale and in scope over time, b) it could play a role in sharing knowledge and development experience across countries. c) It could also play a role in coordinating NDB's partnerships and collaborations with institutions on the continent. d) And importantly, when the Board of Governors approves expansion of the NDB's operations in other countries in Africa, the ARC could also play a leading role in initiating and scaling up the NDB's work in those countries.

Up to now, the NDB has set up a presence in four continents headquarters in Shanghai, regional office/center in Sao Paulo, Johannesburg, and Moscow. Similar to ARC, the ARO and ERC will play important roles in each respective region. These regional centers/offices are also further evidence of the NDB's significant institutional development and should help the Bank secure a foothold in each continent [Ibid., 2018]. By working with strategic partners with strong implementation capability and a shared interest in infrastructure and sustainable development, they could make contributions to enhancing the Bank's overall impact [Ibid., 2017a].

\section{Global and Diverse Partnerships}

In line with the NDB's mandate, the Bank is actively reaching out and engaging in partnerships with diverse actors to pool efforts in supporting global growth and sustainable development. The diverse partners consist of Multilateral Development Banks (MDBs, including major global and regional multilaterals as well as smaller sub-regional institutions), national development banks, commercial banks, enterprises, and academia. Take building partnership with MDBs as an example, the NDB has signed Memoranda of Understanding and Cooperation Agreements with eleven MDBs since 2016. Through the institutionalized partnership, the NDB seeks to undertake joint projects and knowledge exchanges with the World Bank and major regional MDBs (e.g. Asian Development Bank, European Investment Bank, European Bank for Reconstruction and Development) to make the most of their decades of experience. NDB is also engaging with development institutions controlled by EMDCs, such as the Asian Infrastructure Investment Bank (AIIB), the Development Bank of Latin America (CAF), the Eurasian Development Bank and the International Investment Bank.

Put together, these diverse partnerships have important functions for the NDB's performance: to enable the Bank to tap into the expertise of established development institutions; to better access local knowledge on borrowing countries' strategic development priorities, infrastructure and sustainable development issues, national laws and policies; to strengthen its ca- 
pacity to assess and implement projects as well as increasing capillarity of its operations [NDB, 2017a].

\section{Explaining the BRICS Outreach}

\section{BRICS Outreach Motivations}

In our theoretical framework, we considered the G7/8's and to some degree the G20's ambition for "group hegemony" [Bailin, 2005], feeding into three hypotheses for outreach related to effectiveness, legitimacy and socialization. The ambitions of the BRICS have thus far been more modest: similar to the G7/G8, the BRICS wants to contribute to global public goods that correspond with their own interests, but has never shown an aspiration to sit in the cockpit of global governance. However, the BRICS displays characteristics of a counter-group hegemony to the G7. Like the G7, the BRICS countries are held together by a degree of likemindedness. They are state-permeated market economies [Nölke et al., 2015] that are keen on upholding international pluralism in terms of political and economic systems. They share a few grievances and aspirations with regard to the world order and multilateral system, and engage in soft balancing with the Western powers [Mielniczuc, 2013]. In other words, given their different state-society complexes [De Graaff, Van Apeldoorn, 2017], this counter-hegemony pursues a different "social purpose" [Ruggie, 1982] than the G7. Similar to the preponderance of a declining US in the G7, the BRICS both benefits and suffers from the preponderance of a rising China.

As to Hypothesis 1 (effectiveness), one of the most drastic ways of raising effectiveness through outreach was the adoption of South Africa as a full member after a short relationship. For the rest, the BRICS summits are not accompanied by much operational collaboration with outreach partners.

Hypothesis 2 (legitimacy) is to a larger extent confirmed. Rotating BRICS hosts are keen to invite regional neighbors, also establishing ties between the BRICS and regional forums. A similar motivation is visible in the Chinese-led BRICS Plus initiative. These outreach initiatives, and non-members participation to them, legitimize the BRICS and strengthen the image of these five as an alternative major power grouping to the G7.

Hypothesis 3 (socialization) is rather poorly confirmed since there is little operational cooperation that can function as a channel for socialization.

Hypothesis 4 (instrumentalization) is to a notable extent confirmed. The lack of group cohesion opens the door to more individual initiatives using the BRICS platform. In fact, as is also the case in the G7/G8 and G20, the consecutive hosts' regional-based outreach practices, clearly show the way the rotating chairs use the BRICS to enhance their bilateral ties with selected neighbors. In addition, the BRICS Plus efforts reveal China's individual strategy in function of its BRI, in which the BRICS is instrumentalized as a power multiplier - even leading to suspicion of the other members [Hooijmaaijers, 2019]. A similar problem came up in 2019 when president Bolsonaro of Brazil wanted to invite the controversial self-declared president Guaído of Venezuela, which would have given the latter an extra boost of international prestige. This constituted a clear Brazilian foreign policy objective, to which the other BRICS members openly opposed.

In parallel, the NDB forms an exception to this relatively modest picture. We see indications of strong outreach motivation. Adoption of new members is enshrined in the founding document, the strategy and reconfirmed at the 2019 BRICS summit. This might add, depending on the newcomers, to capacity in terms of new capital and better credit ratings. The many partnerships between the NDB and national development banks, commercial banks and mul- 
tilateral development banks must be understood in this context as well. The NDB's establishment of regional centers/offices and the adoption of country-specific approaches enables the Bank to improve its effectiveness [NDB, 2019b] (Hypothesis 1). This motivation will be shown more evidently when the expansion of NDB's membership occurs in the near future. In addition, projects in non-member developing countries will contribute to the global public good of infrastructure and green energy so as to advance the interests of BRICS countries in direct and indirect ways (Hypothesis 1). As to BRICS legitimacy (Hypothesis 2) and socialization (Hypothesis 3), the NDB offers opportunities.

Developing countries will regard the NDB as a form of more sensitive south-south cooperation and appreciate the weaker conditionality compared to the western-dominated multilateral development banks, which indirectly will consolidate the image of BRICS as a useful and necessary counter-hegemonic bloc. At the same time, NDB operations will function as a channel for socialization into BRICS approaches to development. However, since the NDB has chosen for substantial partnerships with other parties, including the western-dominated multilateral development banks, part of the BRICS socialization function will be diluted [Heldt, Schmidtke, 2019].

\section{BRICS Outreach Institutionalization}

Given the common interests and degree of like-mindedness within BRICS, the group could theoretically be well motivated to intensify and institutionalize its outreach. In reality, however, the group struggles to sustain its outreach activities. Unlike the G8's Africa and G5 outreach - which were rooted in a more coherent outreach strategy based on a more cohesive vision of the G8's role and ambition in the world - we do not see the BRICS working with a relatively fixed set of countries for some years.

One of the reasons is that BRICS summitry is still relatively young and that the institutionalization of a lesser priority than the consolidation of the group itself takes time. Still, during the outreach process some political problems came to the surface, which reflect deeper divisions within the group. Our research confirms Hypothesis 5 that the institutionalization of the BRICS outreach is a function of the cohesion of the BRICS outreach strategy, which in its turn is linked to the overall political cohesion of BRICS. Notably, distrust and divergence within the group explain why the BRICS Plus cannot take off as China would like.

What is quite well institutionalized, as we also see in the G7/G8 and G20, is the hosts' choice to invite a selection of regional neighbors. However, the actual selection of countries, as e.g. Bolsonaro's invitation to the self-declared president of Venezuela showed, can still be subject to opposition and rejection within the BRICS group.

The NDB, in contrast, is in itself an expression of strong BRICS institutionalization and a high degree of political cohesion within the thematic domain of infrastructure financing. Within its focused mandate and financial needs in terms of capital and credit ratings, it has a clear incentive for outreach beyond BRICS. This case learns that when a major power grouping creates its standalone multilateral organization, the latter can follow a coherent dynamic of its own, despite political divisions at the higher political levels of BRICS, even though important decisions - e.g. adopting new members of the Bank - will have to be rubberstamped by the BRICS top leadership.

What about the interests and agency of outreach partners? We do not see signs of opposition or reluctance. As mentioned, the BRICS does not risk to engage in a patronizing way with other major powers. One major power, South Africa, was soon adopted as a full member, avoiding that risk from the outset. The outreach partners are willing to be invited to this alternative prestigious club, the more so in a post-Cold War world in which developing and emerging countries like to 
maintain good political and economic relations with both Western and non-western major powers alike. A case in point is Turkey, which at present has a number of serious issues with its Western allies, and is therefore all the more heartened by a BRICS invitation. The lack of institutionalization is not due to outreach partners' attitudes, unlike what happened to the G $8+5$ process.

\section{Conclusion}

Major power groupings are evolving. As a relatively small major power grouping, BRICS has deepened its institutionalization and made its first steps to influence the global political economy in the past decade. However, research on the BRICS outreach remains a gap. Therefore, in this article, we probe into the why and how of BRICS outreach and focus on two interrelated puzzles: a) the motivations and b) the form and degree of institutionalization of the BRICS outreach. We define outreach here as collaborative interaction among the BRICS actors (governments and institutions) and other actors within and outside the BRICS area and we focus on outreach to governments of non-BRICS countries and national top officials representing regional organizations.

We offer a theoretical framework based on the experiences of Gx, considering both commonalities and differences with BRICS. In terms of the motivations of outreach, we draw from "group hegemony" theory to consider the BRICS as being in the initial stage of collectively shaping the global political economy as a counter-group hegemony to the G7. This feeds into three hypotheses for outreach related to effectiveness, legitimacy, and socialization. A fourth hypothesis pertains to the instrumentalization of BRICS outreach by individual members. In terms of the form and degree of outreach institutionalization, inspired by the Gx practices, we draw hypotheses for outreach related to political cohesion and power asymmetry.

At the level of the summit channel, HYP1 (effectiveness) was substantiated modestly. The inclusion of South Africa as a full member was the most drastic way of raising effectiveness. For the rest, the BRICS summits are not accompanied by much operational collaboration with outreach partners so far. HYP2 (legitimacy) is to a larger extent confirmed. BRICS outreach activities, and non-members participation to them, legitimize the BRICS and strengthen the image of these five as an alternative major power grouping to the G7. HYP3 (socialization), however, is poorly confirmed. HYP4 (instrumentalization) is to a notable extent confirmed. The lack of group cohesion opens the door to more individual instrumentalization of the BRICS platform as a power multiplier. For instance, the BRICS Plus reveals China's individual strategy in the function of its BRI, and the attempt of president Bolsonaro of Brazil to invite the controversial self-declared president Guaído of Venezuela reveals Brazilian foreign policy interest. As to the NDB channel, HYP1 (effectiveness) is to a large extent confirmed, given the fact that open membership is enshrined in the founding document, the establishment of regional centers/offices, the adoption of country-specific approaches, the contribution to the global public good of infrastructure and green energy in direct and indirect ways. As to HYP2 (legitimacy) and HYP3 (socialization), the NDB offers opportunities.

In terms of the form and degree of outreach institutionalization, the development of BRICS outreach is an integral part of the overall BRICS institutionalization. It reflects the dynamics of its internal cohesion, how it positions itself in the world and how it is perceived by others. The group could theoretically be well motivated to intensify and institutionalize its outreach, however, at summitry, we find that the group struggles to sustain its outreach activities. Our research confirms HP5 that the institutionalization of the BRICS outreach is a function of the cohesion of the BRICS outreach strategy, which in its turn is linked to the overall political cohesion of BRICS. During the outreach process some political problems came to the surface, which reflect deeper divisions within the group. On the one hand, distrust and divergence with- 
in the group explain why the BRICS Plus cannot take off as China would like. On the other, the BRICS per se is still relatively young; it takes time to further consolidate and institutionalize.

The NDB, in contrast, presents a stronger degree of outreach institutionalization. Actually, the NDB itself is an expression of strong BRICS institutionalization and a high degree of political cohesion within the thematic domain of infrastructure financing. Within its focused mandate and financial needs in terms of capital and credit ratings, it has a clear incentive for outreach beyond BRICS. When the expansion of NDB's membership occurs in the future and more outreach initiatives become operationalized, its influence will be increased and add to the overall BRICS impact.

In sum, this research intends to offer a contribution to the ongoing debate on BRICS and the under-researched BRICS outreach process as part of the overall BRICS institutionalization. Albeit fluctuant, the impact of BRICS outreach in direct and indirect ways should not be overlooked; it can be a long-term strategic investment by BRICS leaders. It creates extra channels for BRICS to consult, coordinate, and position themselves by fostering South-South consensus on several issues. And more importantly, it may help the BRICS to reach a more mature stage as a counter-group hegemony. To better assess the effectiveness and the implications of the still-new BRICS outreach, longer-term research is needed. Furthermore, BRICS is also outreaching with some non-state actors, such as BRICS Business Forum, BRICS Civil Forum, BRICS Youth Forum. In order to present a comprehensive picture of BRICS outreach, future research may include BRICS outreach with non-state actors.

\section{References}

Bailin A. (2005) From Traditional to Group Hegemony: The G7, the Liberal Economic Order and the Core-Periphery Gap. Aldershot: Ashgate.

Bhushan A., Slahub J. (2014) The Muskoka Initiative and Global Health Financing. North-South Institute.

Bay of Bengal Initiative for Multi-Sectoral Technical and Economic Cooperation (BIMSTEC). (2016) BIMSTEC Leaders' Retreat 2016 Outcome Document. Available at: https://www.mea.gov.in/bilateral-documents. htm?dtl/27501/BIMSTEC_Leaders_Retreat_2016_Outcome_Document (accessed 26 November 2019).

Black D. (2012) The G8 and Africa: A Partial Reckoning. Global Governance, vol. 18, no 4, pp. 441-7. Available at: https://www.jstor.org/stable/24526381 (accessed 26 November 2019).

BRIC. (2009) Joint Statement of the BRIC Countries' Leaders. St. Petersburg, 16 June. Available at: http://www. brics.utoronto.ca/docs/090616-leaders.html (accessed 26 November 2019).

BRICS (2011) Sanya Declaration. Sanya, 14 April. Available at: http://www.brics.utoronto.ca/docs/110414leaders.html (accessed 26 November 2019).

BRICS. (2013) eThekwini Declaration. Durban, 27 March. Available at: http://www.brics.utoronto.ca/ docs/130327-statement.pdf (accessed 26 November 2019).

BRICS. (2014a) Treaty for the Establishment of a BRICS Contingent Reserve Arrangement. Fortaleza, 15 July. Available at: http://www.brics.utoronto.ca/docs/140715-treaty.html (accessed 26 November 2019).

BRICS. (2014b) Agreement on the New Development Bank. Fortaleza, 15 July. Available at: https://www.ndb. int/wp-content/themes/ndb/pdf/Agreement-on-the-New-Development-Bank.pdf (accessed 26 November 2019).

BRICS. (2014c) Fortaleza Declaration. Fortaleza, 15 July. Available at: http://www.itamaraty.gov.br/en/ pressreleases/5705-vi-brics-summit-fortaleza-declaration-july-15-2014 (accessed 26 November 2019).

BRICS. (2015) Ufa Declaration. Ufa, 9 July. Available at: http://www.brics.utoronto.ca/docs/150709-ufadeclaration_en.pdf (accessed 26 November 2019).

BRICS. (2016) Goa Declaration. Goa, 16 October. Available at: https://www.mea.gov.in/bilateral-documents. $\mathrm{htm}$ ?dtl/27491/Goa+Declaration+at+8th+BRICS+Summit (accessed 26 November 2019). 
BRICS. (2017) Xiamen Declaration. Xiamen, 4 September. Available at: http://www.brics.utoronto.ca/ docs/170904-xiamen.pdf (accessed 26 November 2019).

BRICS. (2018) Johannesburg Declaration. Johannesburg, July 25-27. Available at: http://www.brics.utoronto. ca/docs/180726-JOHANNESBURG_DECLARATION-26_JULY_2018_as_at_07h11.pdf (accessed June 2020).

BRICS. (2019) Brasilia Declaration. Brasilia, 14 November. Available at: http://brics2019.itamaraty.gov.br/ images/documentos/Braslia_Declaration_-_hiperlinks_como_est_no_site_28-11.pdf (accessed 26 November2019).

Cooper A.F. (2008) The Heiligendamm Process: Structural Reordering and Diplomatic Agency. Emerging Powers in Global Governance: Lessons From the Heiligendamm Process (A.F. Cooper, A. Antkiewicz (eds)). Waterloo: Wilfrid Laurier Press.

Cooper A.F., Momani B. (2014) Re-Balancing the G-20 from Efficiency to Legitimacy: The 3G Coalition and the Practice of Global Governance. Global Governance, vol. 20, no 2, pp. 213-32. Available at: https://www. jstor.org/stable/24526279 (accessed 26 November 2019).

Cooper A.F. (2016) The BRICS: A Very Short Introduction. Oxford University Press.

Cornelissen S. (2012) Selling Africa: Japan's G8 Politics and Its Africa Diplomacy. Global Governance, vol. 18, no 4, pp. 461-70. Available at: https://www.jstor.org/stable/24526383.

Dasgupta S. (2017) China Wants 'BRICS Plus' to Include 'Friendly' Countries, Plan Might Hurt India's Interests. Times of India, 8 March. Available at: https://timesofindia.indiatimes.com/world/china/china-wantsbrics-plus-to-include-friendly-countries-plan-might-hurt-indias-interests/articleshow/57542116.cms (accessed November 2019).

De Coning C. (2017) The BRICS: The Last Line of Defence for Globalisation? Rising Powers Quarterly, vol. 2, no 4, pp. 83-93. Available at: https://risingpowersproject.com/quarterly/brics-last-line-defence-globalisation/ (accessed 8 April 2020).

De Graaff N., van Apeldoorn B. (2017) US Elite Power and the Rise of "Statist" Chinese Elites in Global Markets. International Politics, vol. 54, no 3, pp. 338-55. Available at: https://doi.org/10.1057/s41311-0170031-2.

Dijkhuizen F., Onderco M. (2019) Sponsorship Behaviour of the BRICS in the United Nations General Assembly. Third World Quarterly, vol. 40, no 11, pp. 2035-51. Available at: https://doi.org/10.1080/01436597.20 19.1622411.

Duggan N. (2015) BRICS and the Evolution of a New Agenda Within Global Governance. The European Union and the BRICS: Complex Relations in the Era of Global Governance (M. Rewizorski (ed.)). Springer International. Embassy of the People's Republic of China in the Republic of South Africa (2018) Elements of Remarks by H.E. Ambassador Lin Songtian at South African National Editors Forum (SANEF), 22 August. Available at: http://za.china-embassy.org/eng/sgxw/t1587417.htm (accessed November 2019).

Engel U. (2012) The G8 and Germany's Africa Policy: A Case of Hegemonic Mainstreaming. Global Governance, vol. 18, no 4, pp. 471-6. Available at: https://www.jstor.org/stable/24526384.

Eurasian Economic Commission (EEC). (2018) Agreement Signed on Trade and Economic Cooperation Between EAEU and PRC. Available at: http://www.eurasiancommission.org/en/nae/news/Pages/17-05-2018-5.aspx (accessed December 2019).

Group of 8 (G8). (2000) Summit Meeting in Tokyo Among President Olusegun Obasanjo of the Federal Republic of Nigeria, President Thabo Mbeki of the Republic of South Africa, President Abdelaziz Bouteflica of the Democratic People's Republic of Algeria, Prime Minister Chuan Leekpai of the Kingdom of Thailand and G8 Leaders. Tokyo, 20 July. Available at: http://www.g7.utoronto.ca/summit/2000okinawa/devs.htm (accessed 10 April 2020).

Group of 8 (G8). (2001) Genoa Summit Programme. Available at: https://web.archive.org/web/20051217104822/ http://www.g8italia.it/_en/docs/QKZUPJ11.htm (accessed 22 December 2019).

Group of 8 (G8). (2007) Joint Statement by the German G8 Presidency and the Heads of State and/or Government of Brazil, China, India, Mexico and South Africa on the Occasion of the G8 Summit in Heiligendamm, Germany, 8 June. Available at: http://www.g8.utoronto.ca/summit/2007heiligendamm/g8-2007-joint.pdf (accessed 2 December 2019). 
Heldt E.C., Schmidtke H. (2019) Explaining Coherence in International Regime Complexes: How the World Bank Shapes the Field of Multilateral Development Finance. Review of International Political Economy, vol. 26, no 6, pp. 1-27. Available at: https://doi.org/10.1080/09692290.2019.1631205.

Hooijmaaijers B. (2019) China, the BRICS, and the Limitations of Reshaping Global Economic Governance. The Pacific Review. Available at: https://doi.org/10.1080/09512748.2019.1649298.

Keohane R.O. (1984) After Hegemony: Cooperation and Discord in the World Political Economy. Princeton: Princeton University Press.

Kirton J.J. (2008) From G8 2003 to G13 2010? The Heiligendamm Process's Past, Present and Future. Emerging Powers in Global Governance: Lessons From the Heiligendamm Process (A.F. Cooper, A. Antkiewicz (eds)). Waterloo: Wilfrid Laurier Press.

Kirton J.J. (2015) Going Global: The G8's Adaptation to Rising Powers. Rising Powers and Multilateral Institutions (D. Lesage, T. van de Graaf (eds)). Springer.

Kirton J.J. (2015) Explaining the BRICS Summit Solid, Strengthening Success. International Organisations Research Journal, vol. 10, no 2, pp. 9-38. Available at: https://doi.org/10.17323/1996-7845-2015-02-09.

Kremlin. (2015a) Joint Statement on Cooperation on the Construction of Joint Eurasian Economic Union and the Silk Road Projects. 8 May. Available at: http://kremlin.ru/supplement/4971 (accessed November 2019). (in Russian).

Kremlin. (2015b) Press statements following Russian-Chinese talks. 8 May. Available at: http://en.kremlin.ru/ events/president/transcripts/49433 (accessed November 2019). (in English).

Lake D.A. (1993) Leadership, Hegemony, and the International Economy: Naked Emperor or Tattered Monarch With Potential? International Studies Quarterly, vol. 37, no 4, pp. 459-89. Available at: https://www.jstor. org/stable/2600841.

Larionova M., Shelepov A. (2015) Is BRICS Institutionalization Enhancing Its Effectiveness? The European Union and the BRICS (M. Rewizorski (ed.)). Springer.

Leininger J. (2009) Think Big! Future Prospects of the International Summit Architecture: The G20, G8, G5, and the Heiligendamm Dialogue Process. German Development Institute Discussion Paper no 6/2009. Available at: https://doi.org/10.2139/ssrn.1566959.

Li Y. (2017) BRICS' Synergy With Belt and Road Initiative. Belt and Road Portal, 7 September. Available at: https://eng.yidaiyilu.gov.cn/home/rolling/26990.htm (accessed November 2019).

Luckhurst J. (2016) G20 Since the Global Crisis. Springer.

Mielniczuk F. (2013) BRICS in the Contemporary World: Changing Identities, Converging Interests. Third World Quarterly, vol. 34, no 6, pp. 1075-90. Available at: https://doi.org/10.1080/01436597.2013.802506.

Ministry of Foreign Affairs of the People's Republic of China (PRC). (2017a) Wang Yi: "BRICS Plus" Pattern to Fully Release Vitality of BRICS. 30 August. Available at https://www.fmprc.gov.cn/mfa_eng/zxxx_662805/ t1489003.shtml (accessed 14 November 2019); https://www.fmprc.gov.cn/web/wjb_673085/zzjg_673183/ gjjjs_674249/gjzzyhygk_674253/ydylfh_692140/zyjh_692150/t1461394.shtml (in Chinese).

Ministry of Foreign Affairs of the People's Republic of China (PRC). (2017b) Full Text of President Xi's Speech at Opening Ceremony of BRICS Business Forum, 3 September. Available at: https://www.fmprc.gov.cn/mfa eng/Zxxx_662805/t1489623.shtml (accessed November 2019).

Ministry of Foreign Affairs of the People's Republic of China (PRC). (2019a) Xi Jinping Attends the BRICS Leaders' Meeting, 28 June. Available at: https://www.fmprc.gov.cn/mfa_eng/topics_665678/xjpcxesgjtfh/ t1677647.shtml (accessed November 2019).

Ministry of Foreign Affairs of the People's Republic of China (PRC). (2019b) Wang Yi Attends the Meeting of BRICS Ministers of Foreign Affairs, 27 July. Available at: https://www.fmprc.gov.cn/web/wjbzhd/t1683857. shtml (accessed November 2019) (in Chinese).

Ministry of Foreign Affairs of the People's Republic of China (PRC). (2019c) Wang Yi Attends the Meeting of BRICS Ministers of Foreign Affairs, 27 September. Available at: https://www.fmprc.gov.cn/mfa_eng/ zxxx_662805/t1704049.shtml (accessed November 2019).

Ministry of Foreign Affairs of the People's Republic of China (PRC). (2019d) Xi's Speech at the BRICS Business Forum Closing Ceremony. Available at: https://www.fmprc.gov.cn/web/ziliao_674904/zt_674979/dnzt_674981/ xzxzt/xjpdxljxgsfw_698719/zxxx_698721/t1715717.shtml (accessed December 2019) (in Chinese). 
Ministry of Foreign Affairs of the People's Republic of China (PRC). (2019e) Xi's Formal Speech at the Meeting of BRICS Leaders' Summit. Available at: https://www.fmprc.gov.cn/web/ziliao_674904/zt_674979/dnzt_674981/ xzxzt/xjpdxljxgsfw_698719/zxxx_698721/t1716043.shtml (accessed December 2019) (in Chinese).

Mpungose L. (2017) Op-Ed: Taking BRICS From Economic Pragmatism to Reformed Global Governance. Daily Maverick, 5 September. Available at: https://www.dailymaverick.co.za/article/2017-09-05-op-ed-taking-brics-from-economic-pragmatism-to-reformed-global-governance/ (accessed November 2019).

Nafey A. (2008) India and the G8. Emerging Powers in Global Governance: Lessons From the Heiligendamm Process (A.F. Cooper, A. Antkiewicz (eds)). Waterloo: Wilfrid Laurier Press.

Naidu S. (2018) As Global Headwinds Batter Countries in BRICS, Can It Stay the Course? The Conversation, 25 July. Available at: http://theconversation.com/as-global-headwinds-batter-countries-in-brics-can-itstaythe-course-100470 (accessed November 2019).

New Development Bank (NDB). (2016) Towards a Greener Tomorrow. Annual Report 2016. Available at https:// www.ndb.int/wp-content/uploads/2017/10/NDB-ANNUAL-REPORT-2016.pdf (accessed October 2019).

New Development Bank (NDB). (2017a) NDB's General Strategy: 2017-2021. Available at: https://www.ndb. int/wp-content/uploads/2017/07/NDB-Strategy-Final.pdf (accessed November 2019).

New Development Bank (NDB). (2017b) NDB Launches Africa Regional Center in Johannesburg, South Africa. Press Release, 17 August. Available at: https://www.ndb.int/press_release/ndb-launches-africa-regionalcenter-johannesburg-south-africa/ (accessed November 2019).

New Development Bank (NDB). (2017c) Speech of President K.V. Kamath at the Opening Ceremony of the Africa Regional Centre of the New Development Bank, Johannesburg, South Africa. President's Desk, 17 August. Available at: https://www.ndb.int/president_desk/speech-mr-k-v-kamath-opening-ceremony-africa-regionalcentre-new-development-bank-johannesburg-south-africa/ (accessed November 2019).

New Development Bank (NDB). (2018a) Agreement between the Federative Republic of Brazil and the New Development Bank on the hosting of the New Development Bank Americas Regional Office in the Federative Republic of Brazil. Available at: https://www.ndb.int/wp-content/uploads/2017/01/AROAgreement-EN.pdf (accessed November 2019).

New Development Bank (NDB). (2018b) NDB President and Brazil's Minister of Finance and Minister of Foreign Affairs Sign Agreement on Hosting of Banks of the Americas Regional Office in Sao Paulo. Press Release, 26 July. Available at: https://www.ndb.int/press_release/ndb-president-minister-foreign-affairs-brazilsign-agreement-hosting-banks-americas-regional-office-sao-paulo/ (accessed November 2019).

New Development Bank (NDB). (2019a) Mission. Available at: https://www.ndb.int/about-us/essence/mission-values/ (accessed 26 November 2019).

New Development Bank (NDB). (2019b) Opening Address of Mr. K.V. Kamath, President, New Development Bank at the Fourth Annual Meeting. President's Desk, 1 April. Available at: https://www.ndb.int/president_desk/ opening-address-mr-k-v-kamath-president-new-development-bank-fourth-annual-meetingapril-1-2019/ (accessed December 2019).

New Development Bank (NDB). (2019c) Agreement Between the Government of the Russian Federation and the New Development Bank on the Hosting of the New Development Bank Eurasian Regional Centre in the Russian Federation. Brasilia, 13 November. Available at: https://www.ndb.int/wp-content/uploads/2019/12/HCA_Eurasian_Regional_Centre_EN.pdf (accessed December 2019).

New Development Bank (NDB). (2019d) Host Country Agreement for NDB's Eurasian Regional Centre in Moscow, Russia Signed in Brasilia. Press Release, 13 November. Available at: https://www.ndb.int/press_release/ host-country-agreement-ndbs-eurasian-regional-center-moscow-russia-signed-brasilia/ (accessed December 2019).

New Development Bank (NDB). (2020) List of Memoranda of Understanding and Cooperation Agreements. Available at: https://www.ndb.int/partnerships/list-of-partnerships/ (accessed January 2020).

Nolke A., ten Brink T., Claar S., May C. (2015) Domestic Structures, Foreign Economic Policies and Global Economic Order: Implications From the Rise of Large Emerging Economies. European Journal of International Relations, vol. 21, no 3, pp. 538-67. Available at: https://doi.org/10.1177\%2F1354066114553682. 
Purushothaman C. (2019) Dinesh Asked: What is 'BRICS Plus' and Its Impact on India? Ask an Expert, Manohar Parrikar Institute for Defence Studies and Analyses (IDSA). Available at: https://idsa.in/askanexpert/what-isBRICS-plus-and-its-impact-on-India (accessed November 2019).

Ruggie J.G. (1982) International Regimes, Transactions, and Change: Embedded Liberalism in the Postwar Economic Order. International Organization, vol. 36, no 2, pp. 379-415. Available at: https://doi.org/10.1017/ S0020818300018993.

Shaw T.M., Antkiewicz A., Cooper A.F. (2008) The Logic of the B(R)ICSAM Model for Global Governance. Emerging Powers in Global Governance: Lessons From the Heiligendamm Process (A.F. Cooper, A. Antkiewicz (eds)). Waterloo: Wilfrid Laurier Press.

Shelepov A. (2018) BRICS Engagement With International Institutions for Better Governance. BRICS and Global Governance (J.J. Kirton, M. Larionova (eds)). Routledge.

Siddiqui S. (2017) The BRICS-Plus Paradigm. China.org.cn, 26 March. Available at: http://www.china.org.cn/ opinion/2017-03/26/content_40501457.htm (accessed November 2019).

Stuenkel O. (2013) The Financial Crisis, Contested Legitimacy, and the Genesis of Intra-BRICS Cooperation. Global Governance, vol. 19, no 4, pp. 611-30. Available at: https://www.jstor.org/stable/24526396.

Stuenkel O. (2015) The BRICS and the Future of Global Order. Lexington Books.

Stuenkel O. (2019) In Spite of Bolsonaro, China Quietly Deepens its Influence in Brazil. Americas Quarterly, 12 November. Available at: https://www.americasquarterly.org/content/spite-bolsonaro-china-quietly-deepens-its-influence-brazil (accessed November 2019).

Taylor I. (2012) Spinderella on Safari: British Policies Toward Africa Under New Labour. Global Governance, vol. 18, no 4, pp. 449-60. Available at: https://www.jstor.org/stable/24526382.

Woodward R. (2008) Why is the OECD Involved in the Heiligendamm Process? Emerging Powers in Global Governance: Lessons From the Heiligendamm Process (A.F. Cooper, A. Antkiewicz (eds)). Waterloo: Wilfrid Laurier Press.

Xinhua (2017) BRICS Mechanism Will Shine More Brightly: Chinese FM. Available at: http://www.xinhuanet.com/english/2017-03/08/c_136112470.htm (accessed October 2019).

\section{Appendix 1: List of the BRICS Outreach/Plus Partners}

\begin{tabular}{|c|c|c|c|c|c|l|l|}
\hline \multicolumn{9}{|c|}{ List of the BRICS Outreach/Plus Partners } \\
\hline No. & Year & Channel & Format & Country & Organization & \multicolumn{1}{|c|}{ Region } & Outcome \\
\hline 1 & 2009 & Summit & Outreach & $\begin{array}{l}\text { South } \\
\text { Africa }\end{array}$ & & Africa & \\
\hline 2 & 2013 & Summit & Outreach & $\begin{array}{l}15 \text { African } \\
\text { leaders }\end{array}$ & & Africa & \\
\hline 3 & 2013 & Summit & Outreach & & $\begin{array}{l}\text { Africa Union } \\
\text { (AU) }\end{array}$ & Africa & \\
\hline 4 & 2014 & Summit & Outreach & & $\begin{array}{l}\text { The Union of } \\
\text { South Ameri- } \\
\text { can Nations } \\
\text { (UN - ASUR) }\end{array}$ & $\begin{array}{l}\text { South } \\
\text { America }\end{array}$ & \\
\hline 5 & 2014 & Summit & Outreach & & $\begin{array}{l}\text { The Com- } \\
\text { munity of } \\
\text { Latin American } \\
\text { and Carib- } \\
\text { bean States } \\
\text { (CELAC) }\end{array}$ & $\begin{array}{l}\text { Latin } \\
\text { American \& } \\
\text { Caribbean }\end{array}$ & \\
\hline
\end{tabular}




\begin{tabular}{|c|c|c|c|c|c|c|c|}
\hline \multicolumn{8}{|c|}{ List of the BRICS Outreach/Plus Partners } \\
\hline No. & Year & Channel & Format & Country & Organization & Region & Outcome \\
\hline 6 & 2015 & Summit & Outreach & & $\begin{array}{l}\text { The Shanghai } \\
\text { Cooperation } \\
\text { Organization } \\
\text { (SCO) }\end{array}$ & Eurasia & \\
\hline 7 & 2015 & Summit & Outreach & & $\begin{array}{l}\text { The Eurasian } \\
\text { Economic Un- } \\
\text { ion (EAEU) }\end{array}$ & $\begin{array}{l}\text { Eurasia / } \\
\text { Central and } \\
\text { northern Asia } \\
\text { and Eastern } \\
\text { Europe }\end{array}$ & $\begin{array}{l}8 \text { May } 2015 \text { - Joint Statement on } \\
\text { Cooperation on the Construction of } \\
\text { Joint Eurasian Economic Union and } \\
\text { the Silk Road Projects; } \\
17 \text { May } 2018 \text { - Agreement on trade } \\
\text { and economic cooperation between } \\
\text { the Eurasian Economic Union } \\
\text { (EAEU) and the People's Republic } \\
\text { of China (PRC); } \\
10 \text { Oct } 2019 \text { - Agreement on trade } \\
\text { and economic cooperation between } \\
\text { the Eurasian Economic Union } \\
\text { (EAEU) and the People's Republic } \\
\text { of China (PRC) entered into force }\end{array}$ \\
\hline 8 & 2016 & Summit & Outreach & & $\begin{array}{l}\text { Bay of Bengal } \\
\text { Initiative for } \\
\text { Multi-Sectoral } \\
\text { Technical and } \\
\text { Economic } \\
\text { Coopera- } \\
\text { tion countries } \\
\text { (BIMSTEC) }\end{array}$ & $\begin{array}{l}\text { South } \\
\text { Asia \& South- } \\
\text { east Asia }\end{array}$ & $\begin{array}{l}\text { BIMSTEC Leaders' Retreat } 2016 \\
\text { Outcome Document }\end{array}$ \\
\hline 9 & 2017 & Summit & Plus & Egypt & & Africa & \\
\hline 10 & 2017 & Summit & Plus & Guinea & & Africa & \\
\hline 11 & 2017 & Summit & Plus & Mexico & & $\begin{array}{l}\text { North } \\
\text { America }\end{array}$ & \\
\hline 12 & 2017 & Summit & Plus & Tajikistan & & Central Asia & \\
\hline 13 & 2017 & Summit & Plus & Thailand & & $\begin{array}{l}\text { Southeast } \\
\text { Asia }\end{array}$ & \\
\hline 14 & 2017 & NDB & Outreach & \begin{tabular}{|l|} 
Africa \\
Regional \\
Center in \\
Johan- \\
nesburg \\
(South \\
Africa)
\end{tabular} & & Africa & \\
\hline 15 & 2018 & Summit & Outreach & Ethiopia & & Africa & \\
\hline 16 & 2018 & Summit & Outreach & Angola & & Africa & \\
\hline 17 & 2018 & Summit & Outreach & Zambia & & Africa & \\
\hline 18 & 2018 & Summit & Outreach & Namibia & & Africa & \\
\hline 19 & 2018 & Summit & Outreach & Senegal & & Africa & \\
\hline 20 & 2018 & Summit & Outreach & Gabon & & Africa & \\
\hline 21 & 2018 & Summit & Outreach & Togo & & Africa & \\
\hline
\end{tabular}




\begin{tabular}{|c|c|c|c|c|c|c|c|}
\hline \multicolumn{8}{|c|}{ List of the BRICS Outreach/Plus Partners } \\
\hline No. & Year & Channel & Format & Country & Organization & Region & Outcome \\
\hline 22 & 2018 & Summit & Outreach & Uganda & & Africa & \\
\hline 23 & 2018 & Summit & Outreach & Rwanda & & Africa & \\
\hline 24 & 2018 & Summit & Outreach & & $\begin{array}{l}\text { African Union } \\
\text { (AU) }\end{array}$ & Africa & \\
\hline 25 & 2018 & Summit & Outreach & & $\begin{array}{l}\text { The South- } \\
\text { ern African } \\
\text { Development } \\
\text { Community } \\
\text { (SADC) }\end{array}$ & Africa & \\
\hline 26 & 2018 & Summit & Plus & Argentina & $\begin{array}{l}\text { As Chair of } \\
\text { the G20 and } \\
\text { influential } \\
\text { MERCOSUR } \\
\text { member }\end{array}$ & $\begin{array}{l}\text { South } \\
\text { America }\end{array}$ & \\
\hline 27 & 2018 & Summit & Plus & Indonesia & \begin{tabular}{|l|} 
As Co-Chair \\
of the New \\
Africa-Asia \\
Strategic Part- \\
nership with \\
South Africa \\
and influen- \\
tial ASEAN \\
member
\end{tabular} & $\begin{array}{l}\text { Southeast } \\
\text { Asia }\end{array}$ & \\
\hline 28 & 2018 & Summit & Plus & Egypt & $\begin{array}{l}\text { As Chair of the } \\
\text { G77+China }\end{array}$ & Africa & \\
\hline 29 & 2018 & Summit & Plus & Jamaica & \begin{tabular}{|l|} 
As incoming \\
Chair of CARI- \\
COM
\end{tabular} & $\begin{array}{l}\text { Caribbean } \\
\text { Sea }\end{array}$ & \\
\hline 30 & 2018 & Summit & Plus & Turkey & $\begin{array}{l}\text { As Chair of the } \\
\text { OIC }\end{array}$ & $\begin{array}{l}\text { Western Asia } \\
\text { \& Southeast } \\
\text { Europe }\end{array}$ & \\
\hline 31 & 2018 & NDB & Outreach & \begin{tabular}{|l|} 
Americas \\
Regional \\
Office in \\
Sao Paulo \\
(Brazil)
\end{tabular} & & Americas & \\
\hline 32 & 2019 & NDB & Outreach & \begin{tabular}{|l|} 
Eurasian \\
Regional \\
Centre \\
Moscow \\
(Russia)
\end{tabular} & & Eurasia & \\
\hline
\end{tabular}

